\title{
A potent trypanocidal component from the fungus Lentinus strigosus inhibits trypanothione reductase and modulates PBMC proliferation
}

\author{
Betania Barros Cota, Luiz Henrique Rosa/ ${ }^{++}$, Elaine Maria Souza Fagundes/ ${ }^{+++}$, \\ Olindo Assis Martins-Filho', Rodrigo Correa-Oliveira², Alvaro José Romanha ${ }^{3}$, \\ Carlos Augusto Rosa ${ }^{4}$, Carlos Leomar Zani/ ${ }^{+}$
}

\begin{abstract}
Laboratório de Química de Produtos Naturais ${ }^{1}$ Laboratório de Biomarcadores de Diagnóstico e Monitoração ${ }^{2}$ Laboratório de Imunologia Celular e Molecular ${ }^{3}$ Laboratório de Parasitologia Celular e Molecular, Instituto René Rachou-Fiocruz, Av Augusto de Lima 1715, $30190-002$ Belo Horizonte, MG, Brasil ${ }^{4}$ Departamento de Microbiologia, Instituto de Ciências Biológicas, Universidade Federal de Minas Gerais, Belo Horizonte, MG, Brasil
\end{abstract}

The fungus Lentinus strigosus (Pegler 1983) (Polyporaceae, basidiomycete) was selected in a screen for inhibitory activity on Trypanosoma cruzi trypanothione reductase (TR). The crude extract of L. strigosus was able to completely inhibit TR at $20 \mu \mathrm{g} / \mathrm{ml}$. Two triquinane sesquiterpenoids (dihydrohypnophilin and hypnophilin), in addition to two panepoxydol derivatives (neopanepoxydol and panepoxydone), were isolated using a bioassay-guided fractionation protocol. Hypnophilin and panepoxydone displayed $I C_{50}$ values of 0.8 and $38.9 \mu \mathrm{M}$ in the TR assay, respectively, while the other two compounds were inactive. The activity of hypnophilin was confirmed in a secondary assay with the intracellular amastigote forms of $\mathrm{T}$. cruzi, in which it presented an $I C_{50}$ value of $2.5 \mu \mathrm{M}$. Quantitative flow cytometry experiments demonstrated that hypnophilin at $4 \mu \mathrm{M}$ also reduced the proliferation of human peripheral blood monocluear cells $(P B M C)$ stimulated with phytohemaglutinin, without any apparent interference on the viability of lymphocytes and monocytes. As the host immune response plays a pivotal role in the adverse events triggered by antigen release during treatment with trypanocidal drugs, the ability of hypnophilin to kill the intracellular forms of $\mathrm{T}$. cruzi while modulating human PBMC proliferation suggests that this terpenoid may be a promising prototype for the development of new chemotherapeutical agents for Chagas disease.

Key words: fungal natural products - Chagas disease - drug discovery - immunomodulators - Basidiomycota

Chagas disease is caused by the protozoan parasite Trypanosoma cruzi and affects millions of people in Latin America, having an enormous economic and social impact in the endemic areas. These patients rely on treatment with nitrofuran (nifurtimox; Bayer) or nitroimidazol (benznidazole; Roche), medicines that display little or no activity in chronic infections, in spite of their beneficial effect during the acute phase of the disease (Cançado 2002, Coura \& Castro 2002). However, significant differences in the therapeutic effectiveness are observed between these two drugs, especially when considering distinct geographical areas, which is probably due to the occurrence of naturally resistant and susceptible T. cruzi strains (Filardi \& Brener 1987, Toledo et al. 2003). Furthermore, both drugs cause several side effects that contribute to their reduced use in clinical medicine (Cançado 1985). Thus, new compounds are needed to develop more effective medicines to treat Chagas disease, espe-

\footnotetext{
Financial support: Fapemig, Capes, CNPq, Fiocruz

+ Corresponding author: zani@cpqrr.fiocruz.br

++ Current address: Laboratório de Microbiologia, Instituto de Ciências Exatas e Biológicas, Universidade Federal de Ouro Preto, Ouro Preto, MG, Brasil

+++ Current address: Departamento de Fisiologia e Biofísica, Universidade Federal de Minas Gerais, Belo Horizonte, MG, Brasil

Received 12 December 2007

Accepted 9 May 2008
}

cially in its chronic phase, is needed (Schmidt \& KrauthSiegel 2002, Nwaka \& Ridley 2003). However, due to low profit prospects, the development of new trypanocidal drugs is not attractive to the pharmaceutical industry (Nwaka \& Ridley 2003). Thus, this endeavor is being conducted mainly in academic laboratories (Fairlamb 1999).

Among the many different strategies for drug discovery, screening the local biodiversity for bioactive natural products using appropriate bioassays is an interesting alternative for researchers in affected areas, especially in countries with a rich biodiversity. There is a vast literature describing that natural products produced by plants, fungi and other organisms are the direct source of or inspiration for many of the currently available medicines (Newman \& Cragg 2007). In this regard, our group screens the Brazilian biodiversity for new bioactive natural products using in vitro bioassays related to neglected diseases, especially Chagas disease and leishmaniasis (Ribeiro et al. 1997, Rosa et al. 2005, 2006). We evaluated more than 3,000 extracts from plant and fungi using an inhibition assay with trypanothione reductase (TR) (unpublished results). This enzyme is a validated molecular target in Trypanosoma and Leishmania species (Fairlamb et al. 1985, Dumas et al. 1997, Tovar et al. 1998, Krieger et al. 2000). As a result of the screening, we found that the ethyl acetate extract of the culture of Lentinus strigosus, a basidiomycete fungus belonging to the Polyporaceae family (Pegler 1983), was able to inhibit $100 \%$ of the enzyme activity at $20 \mu \mathrm{g} / \mathrm{ml}$. 
Species from the genus Lentinus are normally saprophytic, lamellate wood-decaying basidiomycetes (Kirk et al. 2001). Most of its 40 species grow in the tropics, although some can be found in the boreal region (Pegler 1983). Previous investigations on the chemical composition of Lentinus species identified several sesquiterpenes from L. lepideus (Hanssen 1982, 1985) and L. connatus (Rukachaisirikul et al. 2005) and benzoquinones from L. degener (Anchel et al. 1948) and L. adhaerens (Lauer et al. 1991). However, to the best of our knowledge, no investigations studying TR inhibitors were performed with any species from this genus, and this is the first study on the species $L$. strigosus.

Here, we describe the bioassay-guided isolation and identification of the active compounds present in L. strigosus extract. We also show that one of these compounds, the terpenoid hypnophilin, has an interesting biological activity profile, making it an attractive lead for further investigations of drugs to treat Chagas disease.

\section{MATERIALS AND METHODS}

General experimental procedures - The optical rotations were measured on a Perkin-Elmer 341 polarimeter $\left(25^{\circ} \mathrm{C}\right.$, Na lamp, $\left.589 \mathrm{~nm}\right)$. Infrared spectra were obtained on a Shimadzu FTIR-8400, with the samples in KBr pellets. ${ }^{1} \mathrm{H}(400 \mathrm{MHz}),{ }^{13} \mathrm{CNMR}(100 \mathrm{MHz})$, DEPT, HMQC, and HMBC NMR spectra were measured on a Brucker DRX 400 spectrometer. Electron impact $(70 \mathrm{eV})$ lowresolution mass spectra (EI-MS) were measured with a Shimadzu QP5050A spectrometer, equipped with a direct insertion probe. Electrospray ionization mass spectra (ESI-MS) were measured on a Thermo Finnigan LCQ-Advantage spectrometer.

Biological material - The L. strigosus (Schwein) Fr. isolate was deposited in the UFMGCB collection (Universidade Federal de Minas Gerais, Brazil) and received the code UFMGCB975. The specimen was identified using classical taxonomic methods (Pegler 1983).

Fungus fermentation - The fungus was grown on malt extract agar (MEA, Difco, US) and transferred (three $5 \mathrm{~mm}$ discs) to ten $250 \mathrm{ml}$ Erlenmeyer flasks containing $25 \mathrm{ml}$ of MEC medium (malt extract $2 \%$, peptone $0.1 \%$, glucose $1.5 \%$ ). The flasks were shaken at $150 \mathrm{rpm}$ and $28^{\circ} \mathrm{C}$ for five days. The contents of these culture flasks were then transferred to an 81 bioreactor and cultivated for nine days at $28^{\circ} \mathrm{C}$.

Extract preparation - The mycelium was separated from the culture by vacuum filtration, and the filtrate was extracted with ethyl acetate $(5 \times 300 \mathrm{ml}$ for each $1,000 \mathrm{ml}$ of broth). The organic phase was separated and dried over anhydrous sodium sulfate. After filtration, the solution was concentrated in a rotary evaporator at temperatures below $45^{\circ} \mathrm{C}$. The extract was then dried in a vacuum centrifuge at $40^{\circ} \mathrm{C}$ to yield $2.29 \mathrm{~g}$ of a brown gum. An aliquot was used to prepare a stock solution at $20 \mathrm{mg} / \mathrm{ml}$ in dimethylsulphoxide (DMSO), which was used in all biological assays. Both the crude extract and stock solution were stored at $-40^{\circ} \mathrm{C}$.
Isolation and purification - Initially, $100 \mu \mathrm{g}$ of the crude extract was separated in an analytical HPLC column (Shim-pack ODS, $5 \mu \mathrm{m}, 4.6 \times 250 \mathrm{~mm}$ ), using a linear gradient from 10 to $100 \% \mathrm{CH}_{3} \mathrm{OH}$ in $25 \mathrm{~min}$ at $1.0 \mathrm{ml} / \mathrm{min}$. The effluent was monitored with a photodiode array UV detector and collected in a 96-well plate (220 $\mu \mathrm{l}$ per well, 80 wells). The plates were dried in an oven at $40^{\circ} \mathrm{C}$ and then subjected to the TR bioassay to identify the fractions containing metabolites with inhibitory activity (Fig. 1). A semi-preparative fractionation was then performed in a $20 \times 250 \mathrm{~mm}$ reverse-phase HPLC column (Shim-pack prep-ODS, $5 \mu \mathrm{m}$ ), using a $34 \mathrm{~min}$ linear gradient from 15 to $100 \% \mathrm{CH}_{3} \mathrm{CN}$ in $\mathrm{H}_{2} \mathrm{O}$. Five aliquots of approximately $100 \mathrm{mg}$ of crude extract were fractionated at a flow rate of $10 \mathrm{ml} / \mathrm{min}$, with UV detection at 210 and $254 \mathrm{~nm}$. One fraction afforded a white amorphous solid that, upon crystallization with a mixture of $\mathrm{CH}_{2} \mathrm{Cl}_{2}-\mathrm{Hex}$, yielded $32 \mathrm{mg}$ of dihydrohypnophilin (3). The remaining fractions were further fractionated by semi-preparative isocratic normal-phase HPLC (Shimpack prep-Si, $5 \mu \mathrm{m}$, column $20 \times 250 \mathrm{~mm}$ ), eluted with $\mathrm{CH}_{2} \mathrm{Cl}_{2}-\mathrm{MeOH}(95: 5$ or $97: 3)$ at $10 \mathrm{ml} / \mathrm{min}$. This procedure yielded $70 \mathrm{mg}$ of panepoxydone (2), $3.8 \mathrm{mg}$ of neopanepoxydol (1), and $14 \mathrm{mg}$ of hypnophilin (4).

Neopanepoxydol (1) - White amorphous powder; IR (KBr): $v_{\max }=3308(\mathrm{OH}), 2962$ (aliph.), 2862 (aliph.), 1600 $(\mathrm{C}=\mathrm{C}), 1038(\mathrm{C}=\mathrm{C}) \mathrm{cm}^{-1}$. EI-MS $(70 \mathrm{eV}), \mathrm{m} / z 212[\mathrm{M}]^{+}$ $\left(\mathrm{C}_{11} \mathrm{H}_{16} \mathrm{O}_{4}\right) .{ }^{1} \mathrm{H}$ NMR $\left(\mathrm{CDCl}_{3}, 400 \mathrm{MHz}\right): \delta 6.62(1 \mathrm{H}, \mathrm{m}$, $\mathrm{H}-7), 6.53(1 \mathrm{H}, m, \mathrm{H}-8), 4.56$ (1H, broad singlet, $\mathrm{H}-1), 4.21$ $(1 \mathrm{H}, d, J=5.5 \mathrm{~Hz}, \mathrm{H}-5), 3.96(1 \mathrm{H}, d d, J=1.1 ; 5.5 \mathrm{~Hz}, \mathrm{H}-4)$, $3.38(1 \mathrm{H}, d d d, J=0.6 ; 2.5 ; 3.5 \mathrm{~Hz}, \mathrm{H}-2), 3.28(1 \mathrm{H}, d d$, $J=0.6 ; 2.0 ; 4.0 \mathrm{~Hz}, \mathrm{H}-3), 1.81$ (3H, $s, \mathrm{H}-10 /-11), 1.79$ (3H, $s, \mathrm{H}-10$ or $\mathrm{H}-11) .{ }^{13} \mathrm{C}$ NMR $\left(\mathrm{CDCl}_{3}, 100 \mathrm{MHz}\right): \delta 138.08$ (C-9), 132.92 (C-6), 128.34 (C-7), 121.86 (C-8), 73.20 (C-5), 71.00 (C-1 or C-4), 70.90 (C-1 or C-4), 57.81 (C-2), 56.66 (C-3), 26.74 (C-10 or C-11), 18.04 (C-10 or C-11).

Panepoxydone (2) - Pale yellow oil. $[\alpha]^{25}-61^{\circ}(c 0.4$, $\mathrm{CH}_{2} \mathrm{Cl}_{2}$ ). IR (KBr) $v_{\max }=3381(\mathrm{OH}), 2974$ (aliph.), 2880 (aliph.), $1682(\mathrm{C}=\mathrm{O}), 1383(\mathrm{C}-\mathrm{H}), 1043(\mathrm{C}-\mathrm{O}) \mathrm{cm}^{-1}$. ESIMS m/z $209[\mathrm{M}-\mathrm{H}]^{-}\left(\mathrm{C}_{11} \mathrm{H}_{14} \mathrm{O}_{4}\right) .{ }^{1} \mathrm{H}$ NMR $(400 \mathrm{MHz}$, $\left.\mathrm{CDCl}_{3}\right): \delta 6.70(1 \mathrm{H}, d d d, J=1.3,2.5,3.6 \mathrm{~Hz}, \mathrm{H}-5), 5.29$ $(1 \mathrm{H}, \mathrm{q} d, J=1.3,8.8 \mathrm{~Hz}, \mathrm{H}-7), 5.02(1 \mathrm{H}, d, J=8.8 \mathrm{~Hz}$, $\mathrm{H}-8), 4.68(1 \mathrm{H}, s l, \mathrm{H}-4), 3.80(1 \mathrm{H}, d q, J=1.3 ; 2.5 ; 3.6 \mathrm{~Hz}$, $\mathrm{H}-3), 3.46(1 \mathrm{H}, d d, J=1.0 ; 3.6 \mathrm{~Hz}, \mathrm{H}-2), 1.72(6 \mathrm{H}, s, \mathrm{H}-10$ or $\mathrm{H}-11) .{ }^{13} \mathrm{C}$ NMR (100 MHz, $\left.\mathrm{CDCl}_{3}\right): \delta 194.47$ (C-1), 138.98 (C-6), 138.26 (C-9), 137.78 (C-5), 123.68 (C-8), 65.35 (C-7), 63.16 (C-4), 57.71 (C-3), 53.88 (C-2), 25.90 (C-10 or C-11), 18.42 (C-10 or C-11).

Dihydrohypnophilin (3) - White crystals from $\mathrm{CH}_{2} \mathrm{Cl}_{2}$ -Hex. $[\alpha]^{25}{ }_{\mathrm{D}}+135^{\circ}\left(c\right.$ 0.5, $\left.\mathrm{CHCl}_{3}\right)$. IR $(\mathrm{KBr}) v_{\max }=3391$ (OH), 2939 (aliph.), 2858 (aliph.), $1666(\mathrm{C}=\mathrm{C}), 1458$ (aliph.), 1392 (C-H), 1222 (C-O), 1045 (C-O), 957 (C-H), 883 (C-H) $\mathrm{cm}^{-1}$. EI-MS $(70 \mathrm{eV}), \mathrm{m} / z 250[\mathrm{M}]^{+}\left(\mathrm{C}_{15} \mathrm{H}_{22} \mathrm{O}_{3}\right)$. ${ }^{1} \mathrm{H}$ NMR $\left(400 \mathrm{MHz}, \mathrm{CDCl}_{3}\right): \delta 5.32(1 \mathrm{H}, d, J=2.2 \mathrm{~Hz}$, $\mathrm{H}-15 \mathrm{a}), 5.15(1 \mathrm{H}, d, J=2.2 \mathrm{~Hz}, \mathrm{H}-15 \mathrm{~b}), 4.62(1 \mathrm{H}, q$, $J=2.2 \mathrm{~Hz}, \mathrm{H}-5), 3.80(1 \mathrm{H}, d, J=8.4 \mathrm{~Hz}, \mathrm{H}-1), 3.47(1 \mathrm{H}$, $d, J=2.2 \mathrm{~Hz}, \mathrm{H}-6), 2.60(1 \mathrm{H}, m, \mathrm{H}-9), 2.03(1 \mathrm{H}, d d$, $J=8.4,12.0 \mathrm{~Hz}, \mathrm{H}-2), 1.85(1 \mathrm{H}, m, \mathrm{H}-10 \alpha), 1.82$ 


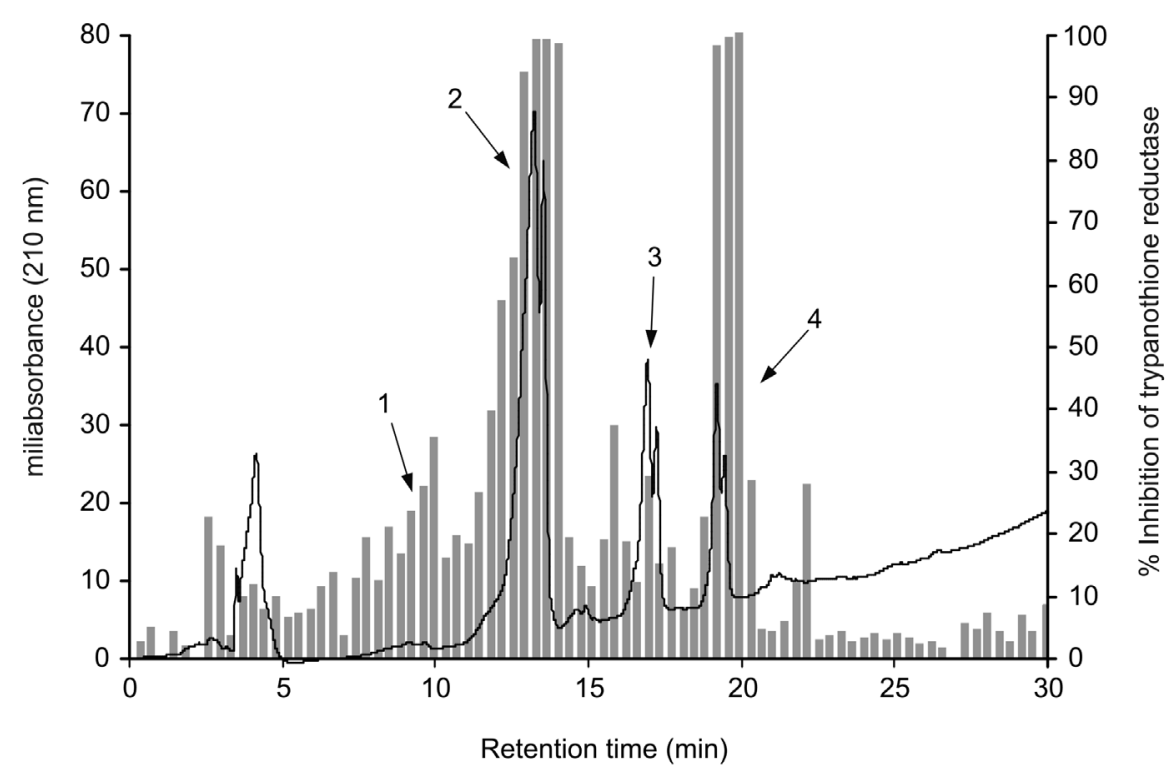

Fig. 1: overlay plot of the analytical chromatogram (line), and the percent inhibition of trypanothione reductase (gray bars) of fractions collected at $22 \mathrm{sec}$ intervals. HPLC conditions: RP-18 column $(250 \times 4.6 \mathrm{~mm}, 5 \mu \mathrm{m}$ particle size) eluted with a gradient of methanol-water from $10 \%$ to $100 \%$ in $25 \mathrm{~min}$, holding at $100 \%$ for $5 \mathrm{~min}$; the eluent was pumped at $1 \mathrm{ml} / \mathrm{min}$, and the effluent detected at $210 \mathrm{~nm}$. Numbered arrows indicate the retention times of the isolated compounds (1: neopanepoxydol; 2: panepoxydone; 3: dihydrohypnophilin; 4: hypnophilin). Assay conditions: see the experimental section.

$(2 \mathrm{H}, d, J=9.0 \mathrm{~Hz}, \mathrm{H}-8), 1.17(3 \mathrm{H}, s, \mathrm{H}-14), 1.13(1 \mathrm{H}, m$, $J=12.0 \mathrm{~Hz}, \mathrm{H}-10 \beta), 1.05(3 \mathrm{H}, s, \mathrm{H}-12), 0.89(3 \mathrm{H}, s$, $\mathrm{H}-13) .{ }^{13} \mathrm{C}$ NMR $\left(100 \mathrm{MHz}, \mathrm{CDCl}_{3}\right): \delta 159.64(\mathrm{C}-4), 112.53$ (C-15), 80.96 (C-1), 75.03, (C-7), 74.19, (C-5), 63.73 (C-6), 55.25 (C-2), 47.55 (C-3), 46.36 (C-10), 44.22 (C-11), 34.81 (C-9), 30.74 (C-8), 26.48 (C-12), 19.78 (C-13), 17.51 (C-14).

Hypnophilin (4) - Colorless oil. $[\alpha]^{25}{ }_{\mathrm{D}}-74^{\circ}$ (c 0.9 , $\mathrm{CHCl}_{3}$ ). IR (KBr) $v_{\max }=3443(\mathrm{OH}), 2937$ (aliph.), 2870 (aliph.), $1728(\mathrm{C}=\mathrm{O}), 1636(\mathrm{C}=\mathrm{C}), 1464(\mathrm{C}-\mathrm{H}), 1375$ (C-H), 1115 (C-O) cm $\mathrm{cm}^{-1}$ EI-MS (70 eV), m/z $248[\mathrm{M}]^{+\bullet}$ $\left(\mathrm{C}_{15} \mathrm{H}_{20} \mathrm{O}_{3}\right) .{ }^{1} \mathrm{H}$ NMR $\left(400 \mathrm{MHz}, \mathrm{CDCl}_{3}\right): \delta 6.13(1 \mathrm{H}$, s, H-15a), 5.45 (1H, s, H-15b), $3.87(1 \mathrm{H}, \mathrm{d}, J=9.0 \mathrm{~Hz}$, H-1), 3.43 (1H, s, H-6), 2.64 (1H, m, H-9), 2.14 (1H, dd, $J=9.0,12.0 \mathrm{~Hz}, \mathrm{H}-2), 1.95$ (2H, m, H-8), 1.90 (1H, m, $\mathrm{H}-10 \alpha), 1.30$ (3H, s, H-14), 1.23 (1H, m, H-10ß), 1.07 (3H, s, H-12), 0.89 (3H, s, H-13). $\left.{ }^{13} \mathrm{C} \mathrm{NMR} \mathrm{(100} \mathrm{MHz,} \mathrm{CDCl}_{3}\right)$ :

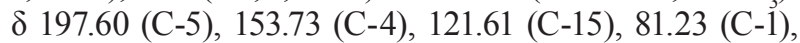
76.04 (C-7), 61.14 (C-6), 56.13 (C-2), 46.12 (C-10), 45.54 (C-3), 44.14 (C-11), 34.52 (C-9); 30.75 (C-8), 26.43 (C-12), 19.66 (C-13), 17.75 (C-14).

Cell preparations - Venous blood from healthy adult volunteers was collected in heparinized tubes and centrifuged over a Ficoll-Hypaque cushion (Histopaque, Sigma, St Louis, MO). Peripheral blood mononuclear cells (PBMC) were collected from the Ficoll/Hypaque interphase and washed three times in RPMI prior to further processing. The cell suspensions were adjusted to $1.5 \times 10^{6}$ cells $/ \mathrm{ml}$.

Viability assays - PBMC viability was determined using a modification of the protocol described by SouzaFagundes et al. (2002). Briefly, the cells were treated with pure compounds at different concentrations for $72 \mathrm{~h}$ at $37^{\circ} \mathrm{C}$ in a $95 \%$ relative humidity atmosphere with $5 \%$
$\mathrm{CO}_{2}$. After this period, the cells were incubated for $10 \mathrm{~min}$ with trypan blue $(0.4 \%$ in $\mathrm{NaCl} 0.9 \%)$. In the flow cytometry experiments, trypan blue fluorescence was measured in the FL2 channel. Fluorescence intensity was used to discriminate viable (non-fluorescent) and non-viable (fluorescent) lymphocytes. Controls with $0.1 \%$ DMSO run in parallel did not demonstrate any differences in cell viability (data not shown).

PBMC culture - All cultures were performed in RPMI-1640 medium (GIBCO, Grand Island, NY), supplemented with $5 \%(\mathrm{v} / \mathrm{v})$ heat-inactivated, pooled human sera type AB (Flow Laboratories, Royaune, UN) and L-glutamine (2 mM, GIBCO, Grand Island, NY). An antibiotic/antimicotic solution containing $1,000 \mathrm{U} / \mathrm{ml}$ penicillin, $1,000 \mu \mathrm{g} / \mathrm{ml}$ streptomycin and $25 \mu \mathrm{g} / \mathrm{ml}$ fungisone (SIGMA, St. Louis, MO) was added to control fungal and bacterial contamination.

Lymphocyte proliferation assay - In vitro cellular proliferation (blastogenesis) was assessed as previously described (Gazzinelli et al. 1983). Briefly, 1 x $10^{6}$ cells $/ \mathrm{ml}$ $\left(1.5 \times 10^{5}\right.$ cells per well) were cultured in complete RPMI-1640 in flat-bottomed microtiter plates (Costar, tissue culture treated polystyrene \# 3512, Corning, NY, USA). The cultures were stimulated with $2.5 \mu \mathrm{g} / \mathrm{ml}$ of PHA (SIGMA, St Louis, MO) and incubated for $72 \mathrm{~h}$ at $37^{\circ} \mathrm{C}$ in a humidified atmosphere containing $5 \% \mathrm{CO}$. The cell proliferation and viability were determined using an MTT (methyl thiazolyl tetrazolium)-based colorimetric assay (Jiang \& Xu 2003). The results were expressed as percent inhibition of the lymphocyte proliferation in relation to the control (without drugs).

Assay with recombinant TR from T. cruzi - The recombinant TR assay was performed according to Hamilton et 
al. (2003) in 96-well plates (Costar 9017, Corning, USA) using Hepes buffer ( $40 \mathrm{mM} \mathrm{pH} \mathrm{7.5)} \mathrm{with} 1$ mM EDTA. Each assay well $(250 \mu \mathrm{l})$ contained enzyme $(6 \mathrm{mU})$, trypanothione $(0.25 \mathrm{nmol})$ and NADPH $(50 \mathrm{nmol})$. The extracts, fractions or pure compounds were added to the above mixture and incubated at $30^{\circ} \mathrm{C}$ during $30 \mathrm{~min}$. After this period, $17.5 \mathrm{nmol}$ of DTNB [5,5'-dithiobis(2-nitrobenzoic acid), Ellman's reagent] was added, and the absorbance (Abs) was measured at $412 \mathrm{~nm}$ in the kinetic mode every $10 \mathrm{~s}$ for $5 \mathrm{~min}$. The resulting slope of the $\delta \mathrm{Abs} / \delta \mathrm{t}$ plot is proportional to DTNB reduction and the enzyme activity (Hamilton et al. 2003). The enzyme inhibition was calculated as the ratio between $(\delta \mathrm{Abs} / \delta \mathrm{t})$ of the experimental wells and that of the controls without drug, that is, percent inhibition $=\left(1-(\delta \mathrm{Abs})_{\exp } /(\delta \mathrm{Abs})_{\text {contr }}\right) \times 100$.

Assay with T. cruzi amastigotes - This assay was performed as described previously by Buckner et al. (1996) using a T. cruzi (Tulahuen strain) expressing the Escherichia coli $\beta$-galactosidase gene. Infective trypomastigote forms were obtained through culture in monolayers of mouse L929 fibroblasts in RPMI-1640 medium $(\mathrm{pH}$ 7.2-7.4) without phenol red (Gibco BRL) plus $10 \%$ fetal bovine serum, $2 \mathrm{mM}$ glutamine and $40 \mu \mathrm{g} / \mathrm{ml}$ gentamycin. For the bioassay, 4,000 L929 cells in $80 \mu \mathrm{l}$ of supplemented medium were added to each well of a 96-well microtiter plate. After an overnight incubation, 40,000 trypomastigotes in $20 \mu \mathrm{l}$ were added to the cells and incubated for $2 \mathrm{~h}$. The medium containing extracelullar parasites was replaced with $200 \mu 1$ of fresh medium and the plate was incubated for an additional $48 \mathrm{~h}$ to establish the infection. The medium was then replaced with solutions of the compounds at different concentrations in fresh medium $(200 \mu \mathrm{l})$, and the plate was incubated for $96 \mathrm{~h}$. After this period, $50 \mu \mathrm{l}$ of $500 \mu \mathrm{M}$ chlorophenol red glycoside in $0.5 \%$ Nonidet P40 was added to each well, and the plate was incubated for $24 \mathrm{~h}$, after which the absorbance at $570 \mathrm{~nm}$ was measured. Controls with uninfected cells, untreated infected cells, and medium only were run in parallel. The results are expressed as percent reduction of the absorbance in the experimental wells in comparison with the control wells with untreated infected cells (percent inhibition $\left.=\left(1-\mathrm{Abs}_{\mathrm{exp}} / \mathrm{Abs}_{\text {contr }}\right) \mathrm{x} 100\right)$. Triplicates were run in the same plate, and the experiments were repeated at least once.

\section{RESULTS}

L. strigosus (Schwein) Fr. was grown in MEC medium, and the culture extracted with ethyl acetate yielded $2.29 \mathrm{~g}$ of a crude extract that was able to inhibit TR activity by $100 \%$ at $20 \mu \mathrm{g} / \mathrm{ml}$. In order to identify the active components of the extract, $100 \mu \mathrm{g}$ of the crude extract was fractionated in an analytical HPLC column, and the effluent was collected in a 96-well microplate $(250 \mu \mathrm{l} /$ well) while recording the UV chromatogram (at $210 \mathrm{~nm}$ ). After solvent elimination, the dry films in the plate were dissolved with the assay buffer, and the solutions were subjected to the TR inhibition assay. The results of this experiment are presented as an overlay plot of the chromatogram and as the percentage of TR inhibition (Fig. 1), clearly showing that the inhibitory activity was concentrated on compounds eluting around 13 and $19 \mathrm{~min}$. The HPLC method was then scaled up to isolate the compounds in sufficient amounts for structural elucidation and $\mathrm{IC}_{50}$ determinations. Four compounds were isolated, either by crystallization of the collected fractions or after further chromatographic steps, as described in the Materials and Methods section. Based on the analysis of their UV, IV, Mass, and NMR spectra and on comparison with data reported in the literature, the compounds were identified as neopanepoxydol (1), panepoxydone (2), dihydrohypnophilin (3) and hypnophilin (4), as shown in Fig. 2. Detailed analysis of the HMQC and HMBC NMR data allowed the unambiguous assignments of C-12 and C-14 chemical shifts in dihydrohypnophilin and hypnophilin, requiring the correction of those proposed by Abate and Abraham (1994). Thus, the attributions for C-12/C-14 in dihydrohypnophilin should be corrected from 17.5/26.5 $\delta$ to $26.48 / 17.51 \delta$, and in hypnophilin from $17.6 / 26.4 \delta$ to 26.43/17.45 $\delta$.

All pure compounds were tested at $20 \mu \mathrm{g} / \mathrm{ml}$ in the TR, amastigote, and PBMC assays (Table I). The results show that panepoxydone and hypnophilin were active in all bioassays while neopanepoxydol and dihydrohypnophilin were inactive. Dose response experiments with the active compounds confirmed these preliminary results, with hypnophilin and panepoxydone disclosing $\mathrm{IC}_{50}$ values around 1 and $39 \mu \mathrm{M}$, respectively (Table II). Hypnophilin was also more active than panepoxydone against intracellular amastigotes, having an $\mathrm{IC}_{50}$ value of $2.5 \mu \mathrm{M}$. Panepoxydone, however, was more effective in inhibiting PBMC proliferation, having an $\mathrm{IC}_{50}$ of $1.3 \mu \mathrm{M}$.

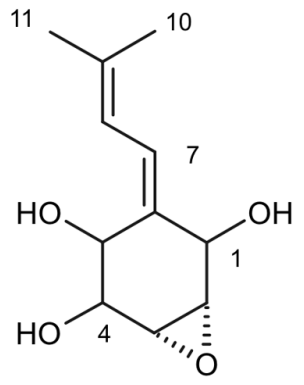

Nepanepoxydol (1)

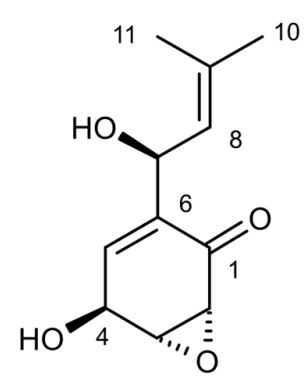

Panepoxydone (2)

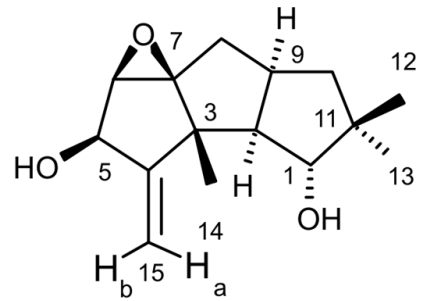

Diidrohypnophilin (3)

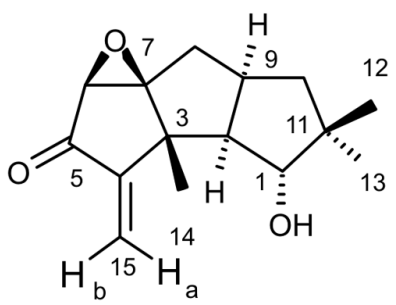

Hypnophilin (4)

Fig. 2: chemical structures of the compounds isolated from the organic extract of Lentinus strigosus. 
TABLE I

Activity of compounds isolated from Lentinus strigosus on trypanothione reductase (TR), intracellular amastigotes (AMA) of Trypanosoma cruzi, and human lymphocyte proliferation (PBMC) assays

\begin{tabular}{lrcr}
\hline Compounds & \multicolumn{3}{c}{$\%$ inhibition $^{a}$ at $20 \mu \mathrm{g} / \mathrm{mL}$} \\
\hline & \multicolumn{1}{c}{ TR } & AMA & PBMC \\
\cline { 2 - 4 } Panepoxydone & $95 \pm 7$ & $95 \pm 7$ & $100 \pm 12$ \\
Hypnophilin & $100 \pm 1$ & $80 \pm 9$ & $100 \pm 17$ \\
Neopanepoxydol & $0 \pm 8$ & $0 \pm 16$ & $8 \pm 13$ \\
Dihydrohypnophilin & $0 \pm 7$ & $0 \pm 11$ & $15 \pm 11$ \\
\hline
\end{tabular}

$a$ : mean value \pm S.D. of at least two independent experments; PBMC: peripheral blood monoclear cell.

TABLE II

$\mathrm{IC}_{50}$ values of panepoxydone and hypnophilin on TR, AMA and PBMC assays

\begin{tabular}{lrcc}
\hline Compounds $^{a}$ & \multicolumn{3}{c}{$\mathrm{IC}_{50}(\mu \mathrm{M})^{b}$} \\
\hline TR & AMA & PBMC \\
\hline Panepoxydone & $38.9 \pm 1.4$ & $8.7 \pm 0.1$ & $1.3 \pm 0.1$ \\
Hypnophilin & $0.8 \pm 0.1$ & $2.5 \pm 0.7$ & $8.9 \pm 1.4$
\end{tabular}

$a: \mathrm{IC}_{50}(\mu \mathrm{M})$ of the standard drugs: TR assay, clomipramine, 2.9 \pm 0.1 ; AMA assay, benznidazole, $1.5 \pm 0.7$; $b$ : mean value \pm S.D. of three independent experiments.

From the experimental data used to construct the dose response curves (data not shown), it was estimated that $4 \mu \mathrm{M}$ hypnophilin is able to block $100 \%$ of TR activity and inhibit $80 \%$ of the growth of intracellular amastigotes, with only minimal inhibitory activity $(20 \%)$ on the proliferation of PHA-stimulated PBMC (Fig. 3). According to the data, at this concentration, panepoxydone would be almost inactive against amastigotes and still present some toxicity to PBMC. To investigate this hypothesis, the impact of panepoxydone and hypnophilin at $4 \mu \mathrm{M}$ on lymphocyte and monocyte subpopulations of the PBMC was evaluated.

The results (Fig. 4a, b) show that panepoxydone induced cell death on the lymphocyte and monocyte populations compared with PBMC control cultures while, as expected, hypnophilin was not cytotoxic. These results were corroborated by quantitative analyses by flow cytometry (Fig. 4c), which showed that panepoxydone reduced the lymphocytes population by $20 \%$, while hypnophilin showed only a $5 \%$ reduction, which is similar to the control culture without drug. Similar results were observed for the monocytes population, where panepoxydone significantly induced cell death (21\%), while the percentage of death caused by hypnophilin mirrored the control without treatment (11\%).

\section{DISCUSSION}

A bioassay-guided procedure based on the inhibition of TR was used to detect and isolate neopanepoxydol (1), panepoxydone (2), dihydrohypnophilin (3) and hypno- $\begin{array}{lll}\text { TR AMA } & \text { PBMC }\end{array}$
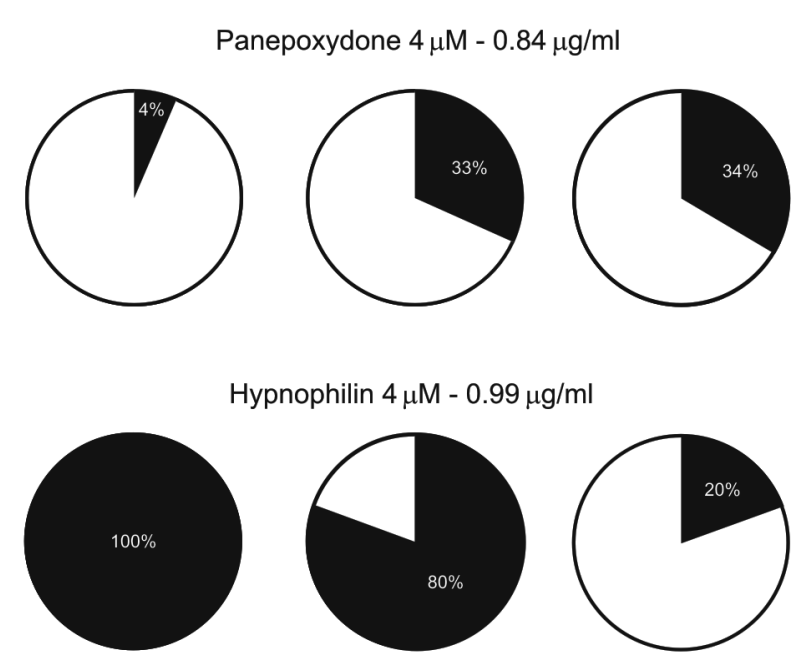

Fig. 3: activity of panepoxydone and hypnophilin on TR, AMA, and PBMC assays at $4 \mu \mathrm{M}$.

philin (4) from L. strigosus. Our results confirm the efficiency of the method based on analytical HPLC and offline bioassay to identify the retention time of the active components (panepoxydone and hypnophilin) present in the extract, facilitating their isolation.

Hypnophilin (4) was previously isolated from the culture of Pleurotellus hypnophilus (Gianetti et al. 1986), Lentinus critinus (Abate \& Abraham 1994) and L. connatus (Rukachaisirikul et al. 2005). Dihydrohypnophilin (3) was isolated from a culture of L. crinitus (Abate \& Abraham 1994) and L. conatus (Rukachaisirikul et al. 2005). Panepoxydone and neopanepoxydol were obtained from fermentations of Panus rudis and Panus conchatus (Kis et al. 1970), while panepoxydone was isolated with hypnophilin from cultures of the L. connatus (Rukachaisirikul et al. 2005) and L. crinitus (Erkel et al. 1996).

Panepoxydone and hypnophilin inhibited TR in the same concentration range of a series of synthesized polyaminoguanidines and polyaminobiguanides $\left(\mathrm{IC}_{50}\right.$ values from 0.95 to $69.47 \mu \mathrm{M}$ ) (Bi et al. 2006). Under our assay conditions, hypnophilin inhibits TR in the low micromolar range $\left(\mathrm{IC}_{50}=1 \mu \mathrm{M}\right)$, making it about three times more active than the reference compound clomipramine $\left(\mathrm{IC}_{50}=3 \mu \mathrm{M}\right)$, a known inhibitor of TR. It is also more active than the macrocyclic spermidine alkaloid lunarine $\left(\mathrm{IC}_{50}=65 \mu \mathrm{M}\right.$, Hamilton et al. 2005), which was isolated from Lunaria biennis. These results indicate that hypnophilin can be considered a good starting point for a medicinal chemistry program aimed at determining derivatives with higher TR inhibitory activity.

Concerning the mechanism by which panepoxydone (2) and hypnophilin (4) inhibit TR, we speculate that it may be similar to that proposed for the alkaloid lunarine (Hamilton et al. 2005), in which the presence of conjugated carbonyl groups make it susceptible to nucleophilic attack by the thiol groups present in the active site of TR. The lack of activity by neopanepoxydol (1) and dihydrohypnophilin (3), which are closely related to two 
(a)

PHA-induced PBMC proliferation

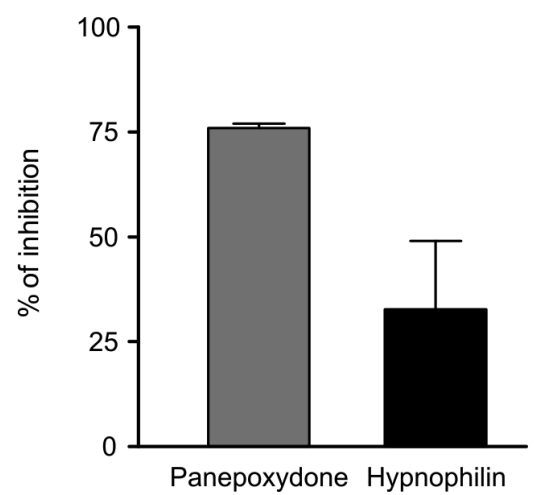

(c)

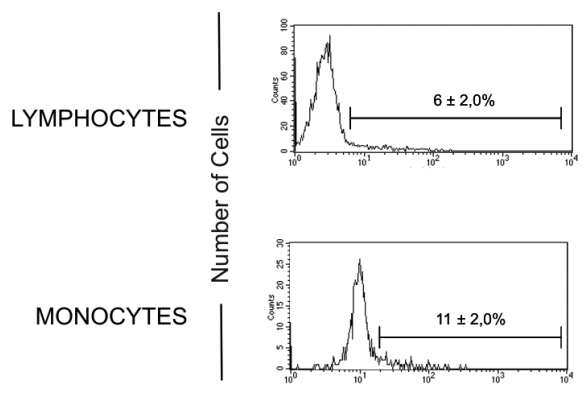

(b)

PBMC viability

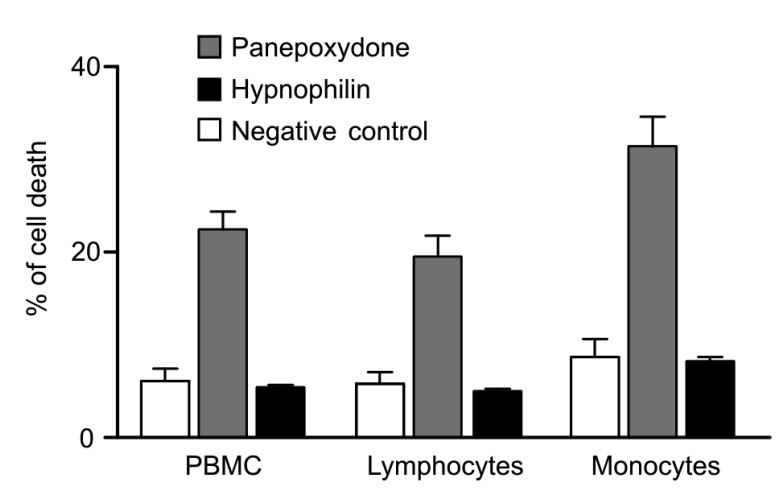

Panepoxydone $4 \mu \mathrm{M}$
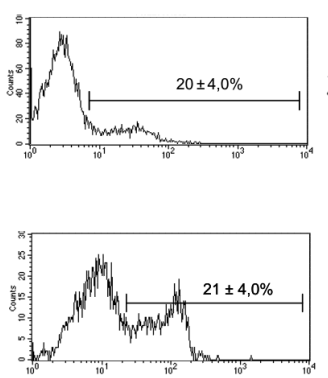

FL3/Trypan Blue
Hypnophilin $4 \mu \mathrm{M}$
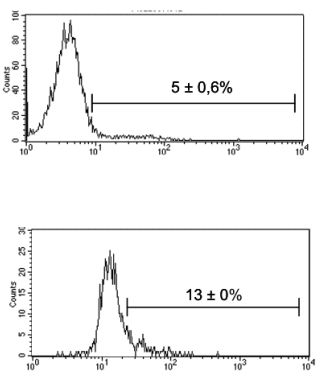

Fig. 4: effect of panepoxydone and hypnophilin on PHA-induced PBMC proliferation, and on the viability of human lymphocytes and monocytes. a: human PBMC were incubated with panepoxydone and hypnophilin for $72 \mathrm{~h}$, and the cell proliferation was estimated using the MTT assay; b: PBMC viability after $18 \mathrm{~h}$ incubation, estimated by Trypan blue labeling and analysis by flow cytometry - PBMC without PHA stimuli and drug was used as the control; c: representative distribution histograms illustrating the non-cytotoxic effect of hypnophilin to human leukocytes - negative control performed as above. Data is representative of four independent experiments.

and four but do not carry the conjugated carbonyl moiety, reinforces this hypothesis.

Besides its activity in the biochemical assay, hypnophilin was also active against the intracellular amastigotes of the Tulahuen strain of T. cruzi infecting L929 cells. Inhibition of the multiplication of $T$. cruzi intracellular amastigotes is clinically relevant because these are the proliferating forms of the parasite. These parasites mature into trypomastigote forms that cause the rupture of the host cells, thus promoting tissue damage in the infected organs, especially the esophagus, colon and heart of chronic patients of Chagas disease. Although circulating parasites cannot be observed by blood inspection in this phase, T. cruzi antigens may trigger the immune system by multiple mechanisms resulting in inflammation and fibrosis. An inflammatory response may result in accumulation and activation of monocytes in addition to increasing the concentration of macrophage-derived cytokines in the plasma (Aliberti et al. 1996). These cytokines can promote an immediate response and also affect organs and tissues.
There is a general consensus that the host immune response plays a pivotal role in the adverse events caused upon the massive antigen release triggered by trypanocidal agents during treatment (Sathler-Avelar et al. 2006). With this in mind, our results show that hypnophilin display a non-cytotoxic antiproliferative activity on PBMC stimulated with PHA, suggesting that, besides its trypanocidal activity, hypnophilin can eventually reduce tissue damage by interfering with the proliferation of cells involved with the immune response.

It is important to mention that the currently available treatment for Chagas disease with benznidazole or nifurtimox is effective mainly during the acute phase of infection, with little effectiveness during chronic disease (Tanowitz et al. 1992, Prata 2001). Furthermore, benznidazole and nifurtimox are more effective against the blood forms observed in the acute phase than the intracellular amastigote forms of the chronic phase $(\mathrm{Mu}-$ elas-Serrano et al. 2002). It must be emphasized that, with control of natural transmission in many areas afflicted by Chagas disease, new cases are episodic and 
the majority of the 18 million patients with T. cruzi are currently in the chronic phase (Prata 2001). In this connection, our findings indicate that hypnophilin is a lead candidate for development of new drugs to treat chronic Chagas disease. Additional studies are needed to characterize the molecular basis of hypnophilin-induced immunomodulatory activity. We speculate that it may involve the up-regulation of IL-10 synthesis, as is the case with benznidazole (Pascutti et al. 2004), or the engagement of other cytokines and/or apoptosis mechanisms that would allow the effective parasite killing in the absence of immunomediated tissue damage.

Two metabolites, panepoxydone and hypnophilin, with significant TR inhibitory activity were isolated from L. strigosus, a tropical basidiomycete investigated for the first time. Hypnophilin disclosed significant antiT. cruzi activity associated with minor non-cytotoxic immunomodulatory activity on human leukocytes, suggesting that it is a good lead candidate for developing new drugs against Chagas disease.

\section{ACKNOWLEDGEMENTS}

To Rosana Alves, Rodrigo Leite and Aline Vaz for their technical assistance. To Prof. Alan Fairlamb (Univ. of Dundee, Scotland) for for providing the recombinant trypanothione reductase, and to Prof. Frederick Buckner (University of Washington, USA) for the Tulahuen strain of $T$. cruzi expressing the $E$. coli $\beta$-galactosidase gene.

\section{REFERENCES}

Abate D, Abraham WR 1994. Antimicrobial metabolites from Lentinus crinitus. J Antibiot 47: 1348-1350.

Aliberti JC, Cardoso MA, Martins GA, Gazzinelli RT, Vieira LQ, Silva JS 1996. Interleukin-12 mediates resistance to Trypanosoma cruzi in mice and is produced by murine macrophages in response to live trypomastigotes. Infect Immun 64: 1961-1967.

Anchel M, Hervey A, Kavanagh F, Polatnick J, Robbins WJ 1948. Antibiotic substances from basidiomycetes III. Coprinus similes and Lentinus degener. Proc Natl Acad Sci U S A 34: 498-499.

Bi X, Lopez C, Bacchi CJ, Rattendi D, Woster PW 2006. Novel alkylpolyaminoguanidines and alkylpolyaminobiguanides with potent antitrypanosomal activity. Bioorg Med Chem Lett 16: 3229-3232.

Buckner FS, Verlinde CLMJ, La Flamme AC, van Voorhis WC 1996. Efficient technique for screening drugs for activity against Trypanosoma cruzi using parasites expressing beta-galactosidase. Antimicrob Agents Chemother 40: 2592-2597.

Cançado JR 1985. Tratamento específico. In JR Cançado, Cardiopatia Chagásica, Fundação Carlos Chagas, Belo Horizonte, p 327-355.

Cançado JR 2002. Long term evaluation of etiological treatment of Chagas disease with benznidazole. Rev Inst Met Trop Sao Paulo 44: 29-37.

Coura JR, Castro SL 2002. A critical review on Chagas disease chemotherapy. Mem Inst Oswaldo Cruz 97: 3-24.

Dumas C, Ouellette M, Tovar J, Cunningham ML, Fairlamb AH, Tamar S, Olivier M, Papadopoulou B 1997. Disruption of the trypanothione reductase gene of Leishmania decreases its ability to survive oxidative stress in macrophages. EMBO J 16: 2590-2598.

Erkel G, Anke T, Sterner O 1996. Inhibition of NF-кB activation by panepoxydone. Biophys Res Commun 226: 214-221.
Fairlamb AH 1999. Future prospects for the chemotherapy of Chagas's disease. Medicina (B Aires) 59: 179-187.

Fairlamb AH, Blackburn P, Ulrich P 1985. Trypanothione-A novel bis(glutationyl)spermidine cofator for glutathione-reductase in trypanosomatids. Science 227: 1485-1487.

Filardi LS, Brener Z 1987. Susceptibility and natural resistance of Trypanosoma cruzi strains to drugs used clinically in Chagas disease. Trans R Soc Trop Med Hyg 81: 755-759.

Gazzinelli G, Katz N, Rocha RS, Colley DG 1983. Immune response during human schistosomiasis mansoni X. Production and standartization of an antigen-induced mitogenic activity by peripheral blood mononuclear cells from treated but not active cases of schistosomiasis. J Immunol 130: 2891-2895.

Gianetti BM, Steffan B, Steglich W, Kupka J, Anke T 1986. Antibiotics from basidiomycetes. Part 24. Antibiotics with a rearranged hirsutane skeleton from Pleurotellus hypnophilus (Agaricales). Tetrahedron 42: 3587-3593.

Hamilton CJ, Saravanamuthu A, Eggleston IM, Fairlamb AH 2003. Ellman's-reagent-mediated regeneration of trypnothione in situ: substrate-economical microplate and time-dependent inhibition assays for trypanothione reductase. Biochem J 369: 529-537.

Hamilton CJ, Saravanamuthu A, Poupat C, Fairlamb AH, Eggleston IM 2005. Time-dependent inhibitors of trypanothione reductase: Analogues of the spermidine alkaloid lunarine and related natural products. Bioorg Med Chem 14: 2266-2278.

Hanssen HP 1982. Sesquiterpene hydrocarbons from Lentinus lepideus. Phytochemystry 21: 1159-1160.

Hanssen HP 1985. Sesquiterpene alcohols from Lentinus lepideus. Phytochemystry 24: 1293-1294.

Jiang J, Xu Q 2003. Immunomodulatory activity of the aqueous extract from rhizome of Smilax glabra in the later phase of adjuvant-induced arthritis in rats. J Ethnopharmacol 85: 53-59.

Kirk PM, Cannon PF, David JC, Stalpers JA 2001. Ainsworth \& Bisby's dictionary of the fungi, 9th ed, CABI Publishing, Britain, $655 \mathrm{pp}$.

Kis Z, Glosse A, Sigg HP, Hruban L, Snatzke G 1970. Die struktur von panepoxydon und verwandten pilzmetaboliten. Helv Chim Acta 53: 1577-1597.

Krieger S, Schwarz W, Ariyanayagam MR, Fairlamb AH, KrauthSiegel RL, Clayton C 2000. Trypanosomes lacking trypanothione reductase are avirulent and show increased sensitivity to oxidative stress. Mol Microbiol 35: 542-552.

Lauer U, Anke T, Hansske F 1991. Antibiotics from basidiomycetes. XXXVIII. 2-methoxy-5-methyl-1,4-benzoquinone, a tromboxane $\mathrm{A}_{2}$ receptor antagonist from $L$ adherens. $J$ Antibiot 44: 59-65.

Muelas-Serrano S, Le-Senne A, Fernandez-Portillo C, Nogal JJ, Ochoa C, Gomez-Barrio A 2002. In vitro and in vivo anti-Trypanosoma cruzi activity of a novel nitro-derivative. Mem Inst Oswaldo Cruz 97: 553-557.

Newman DJ, Cragg GM 2007. Natural products as sources of new drugs over the last 25 years. J Nat Prod 70: 461-477.

Nwaka S, Ridley RG 2003. Virtual drug discovery and development for neglected diseases through public-private partnerships. Nature Rev Drug Discov 2: 919-928.

Pascutti MF, Pitashny M, Nocito AL, Guermonprez P, Amigorena S, Wietzerbin J, Serra E, Bottasso O, Revelli S 2004. Benznidazole, a drug used in Chagas' disease, ameliorates LPS-induced inflammatory response in mice. Life Sci 76: 685-697.

Pegler DN 1983. The genus Lentinus: a world monograph, Kew Bulletin Additional Series X, HMSO, London, 281 pp.

Prata A 2001. Clinical and epidemiological aspects of Chagas disease. Lancet Infect Dis 1: 92-100. 
Ribeiro A, Piló-Veloso D, Romanha AJ, Zani CL 1997. Trypanocidal flavonoids from Trixis vauthieri. J Nat Prod 60: 836-838.

Rosa LH, Cota BB, Machado KMG, Rosa CA, Zani CL 2005. Antifungal compound produced by Oudemansiella canarii (Basidiomycota). World J Microbiol Biotechnol 21: 983-987.

Rosa LH, Souza-Fagundes EM, Machado KMG, Alves TMA, Romanha AJ, Oliveira RC, Rosa CA, Zani CL 2006. Cytotoxic, immunosuppressive and tripanocidal activities of agrocybin, a polyacetylene produced by Agrocybe perfecta (Basidiomycota). World J Microbiol Biotechnol 22: 539-545.

Rukachaisirikul V, Tansakul C, Saithong S, Pakawatchai C, Isaka M, Suvannakad R 2005. Hirsutane sesquiterpenes from the fungus Lentinus connatus BCC 8996. J Nat Prod 68: 1674-1676.

Sathler-Avelar R, Vitelli-Avelar DM, Massara RL, Borges JD, Lana M, Teixeira-Carvalho A, Dias JC, Eloi-Santos SM, Martins-Filho OA 2006. Benznidazole treatment during early-indeterminate Chagas disease shifted the cytokine expression by innate and adaptive immunity cells toward a type 1-modulated immune profile. Scand J Immunol 64: 554-563.
Schmidt A, Krauth-Siegel R 2002. Enzymes of the trypanothione metabolism as targets for antitrypanosomal drug development. Curr Top Med Chem 2: 1239-1259.

Souza-Fagundes E, Queiroz ABR, Martins-Filho O, Gazzinelli G, Corrêa-Oliveira R, Alves TMA, Zani CL 2002. Screening and fractionation of plant extracts with antiproliferative activity on human peripheral blood mononuclear cells. Mem Inst Oswaldo Cruz 97: 1207-1212.

Tanowitz HB, Kirchhoff LV, Simon D, Morris SA, Weiss LM, Wittner M 1992. Chagas disease. Clin Microbiol Rev 5: 400-419.

Toledo MJ, Bahia MT, Carneiro CM, Martins-Filho O, Tibayrenc M, Barnabe C, Tafuri WL, Lana M 2003. Chemotherapy with benznidazole and itraconazole for mice infected with different Trypanosoma cruzi clonal genotypes. Antimicrob Agents Chemother 47: 223-230.

Tovar J, Cunningham ML, Smith AC, Croft SL, Fairlamb AH 1998. Down-regulation of Leishmania donovani trypanothione reductase by heterologous expression of a trans-dominant mutant homologue: effect on parasite intracellular survival. Proc Natl Acad Sci U S A 95: 5311-5316. 